\title{
DAMPAK PENGANGKATAN ARTEFAK BAWAH LAUT TERHADAP KERUSAKAN TERUMBU KARANG BERDASARKAN INDIKATOR TUTUPAN SUBSTRAT DAN PARAMETER LINGKUNGAN
}

\author{
IMPACT OF UNDERWATER SEA ARTEFACTS EXPLORATION TO \\ CORAL REEFS DAMAGE BASED ON THE SUBSTRATE CLOSURE INDICATOR
}

\author{
Ofri Johan ${ }^{1}$, Ira Dillenia ${ }^{2}$, Rainer Arif Troa ${ }^{2}$, Eko Triarso ${ }^{2}$ \\ ${ }^{1}$ Balai Riset Budidaya Ikan Hias \\ J1. Perikanan No. 13, Pancoran Mas, Kota Depok, Jawa Barat. 16436. \\ ${ }^{2}$ Pusat Riset Kelautan. Komplek Bina Samudera \\ J1. Pasir Putih II Lantai 4, Ancol Timur, Jakarta Utara 14430-DKI Jakarta. \\ e-mail : ofrijohan@kkp.go.id
}

Diterima tanggal: 14 Agustus 2017 ; Diterima setelah perbaikan: 27 November 2017 ; Disetujui tanggal: 6 Desember 2017

\begin{abstract}
ABSTRAK
Artefak bawah laut yang merupakan bagian dari situs arkeologi maritim yang memiliki nilai sejarah yang tinggi dan sering ditemukan pada kawasan ekosistem terumbu karang. Keberadaannya mungkin dapat memberikan dampak positif di bidang pariwisata, namun bagaimana dampaknya terhadap lingkungan belum dikaji jika dilakukan pengangkatan apabila artefaknya memiliki nilai lebih tinggi yang perlu diselamatkan. Penelitian ini telah dilakukan pada Situs Kelarik Dalam, Perairan Karang Semapi, Natuna pada tiga waktu berbeda yaitu tanggal 11 - 22 April 2016, 6 - 11 Mei 2017 dan 7 - 11 September 2017. Penelitian bertujuan untuk melihat dampak pengangkatan artefak terhadap kondisi terumbu karang disekitarnya sebagai dasar informasi untuk mengantisipasi rencana pengangkatan artefak secara resmi nanti oleh pemerintah. Penelitian menggunakan metode transek foto bawah air dengan ukuran $58 \times 44 \mathrm{~cm}$. Garis transek dibentangkan dari titik nol di lokasi pusat artefak ditemukan dengan membentangkan 4 rol meteran sepanjang $30 \mathrm{~m}$ ke semua arah mata angin yaitu utara, selatan, timur dan barat. Pengambilan foto dilakukan setiap 1 meter kemudian dianalisa dengna program CPCe dengan menetapkan 30 titik sampel setiap fotonya. Masing-masing transek dibagi 3 zona sesuai jarak dari pusat artefak yaitu 0-10 $\mathrm{m}$ (Zona 1), 10-20 m (Zona 2) dan 20-30 m (Zona 3), berturut-turut mewakili lokasi terdekat, sedang dan terjauh. Data yang dikumpulkan adalah tutupan karang hidup dan tutupan substrat kategori lain dan jenis karang. Hasil penelitian diperoleh terdapat perbedaan tutupan karang hidup antara lokasi yang dekat 0-10 m (6,9\%), sedang 10-20 m (20,3\%) dan terjauh 20$30 \mathrm{~m}(18,5 \%)$. Lokasi terdekat terdampak oleh aktifitas pengangkatan artefak akibat sering terpapar sedimen dan kekeruhan perairan dengan lebih jelas lagi ditandai oleh tingginya rubble $(26,4 \%)$ dan rock $(50,4 \%)$. Jarak sedang dan terjauh memiliki tutupan karang yang lebih tinggi dibandingkan lokasi terdekat. Perlu pertimbangan yang bijak untuk pengangkatan artefak yang ada di kawasan ekosistem terumbu karang dengan memperhatikan dampak kematian terhadap biota yang ada di sekitarnya termasuk terumbu karang.
\end{abstract}

Kata kunci : pengangkatan, artefak bawah laut, kerusakan terumbu karang, tutupan substrat, Kekeruhan.

\section{ABSTRACT}

Underwater artefacts as maritime archaeological site which has historical value and often found in the coral reef ecosystem. Its existence can have a positive impact in tourism, how the impact toward environmental was not study yet if it is need to do collection when the value of artifacts is higher which have to save it. This research was conducted in Kelarik Dalam Site, Semapi Reef Waters of Natuna on three different time that on April 11-22, 2016, Mei 6-11, 2017 and September 7 - 11, 2017. The study aims to see the impact artifacts collection on the coral reef condition on surrounding area as based information to anticipate collecting artefact plan legally by goverment. The study used underwater photos transect method with $58 \times 44 \mathrm{~cm}$ square size. Each transect divided by 3 according to the distance from the artifact center that is $0-10 \mathrm{~m}$ (Zone 1), 10-20 m (Zone 2) and 20-30 m (Zone 3) as representative of nearest, middle and furthers area respectively. The data collected were live coral cover, coral species and other substrate cover categories. The results showed that there was a difference of live coral cover between 0-10m (6.9\%), medium distance 10-20m (20,3\%) and farthest distance 20-30m $(18,5 \%)$. The nearest location is impacted by artificial collection activity due to frequent exposure to sediment and turbidity of the waters which more clearly explain with have high rubble $(26,4 \%)$ and rock $(50,4 \%)$. Medium and farthest distances have higher coral cover compared to nearby locations. It needs a wise consideration for the removal of existing artifacts in

Dampak Pengangkatan Artefak Bawah Laut Terhadap Kerusakan Terumbu Karang Berdasarkan Indikator Tutupan Substrat dan Parameter Lingkungan - Ofri Johan, Ira Dillenia, Rainer Arif Troa dan Eko Triarso 
Keywords: substrate, life coral cover, artifacts, turbidity, dead coral.

\section{PENDAHULUAN}

Kapal karam kuno yang merupakan bagian dari situs arkeologi maritim menjadi aset yang sangat berharga bagi negara sebagai catatan sejarah tentang peradaban nenek moyang dan hubungan antar wilayah nusantara dan antar wilayah lainnya di dunia dengan adanya interaksi perdagangan, pertukaran budaya, peradaban dan kepercayaan dimasa lampau. Lalu lintas pelayaran antar wilayah kerajaan sangatlah tinggi, karena transportasi yang ada pada saat itu hanya lah kapal, sehingga pada masa dulunya nenek moyang kita sudah terkenal dengan istilah nenek moyang kita bangsa pelaut, karena pada zaman itu nenek moyang kita banyak berinteraksi dengan laut dan terkenal keberaniannya melintasi lautan. Perkembangan dibidang bahari sangat berkembang apabila dibandingkan dengan bidang lain. Kawasan perkotaan yang berkembang dan ramai biasanya yang berada di pinggir laut dan sungai yang lebih dekat akses transportasinya dimana laut dan sungai merupakan transportasi andalan utama pada saat itu.

Alat transportasi kapal pada masa itu telah membawa muatan-muatan barang perniagaan dari wilayah
Indonesia dan dari wilayah lain yang berfungsi sebagai, alat tukar dalam jual beli. Barang-barang tersebut antara lain berupa keramik, porselin, uang koin, guci, logam mulia, dan senjata perang pada masa itu yang saat ini ditemukan kembali menjadi bernilai ekonomi tinggi karena ada nilai sejarah kemaritiman yang tersimpan di dalamnya.

Berdasarkan laporan Pusat Riset Kelautan, Badan Riset dan Sumber Daya Manusia Kelautan dan Perikanan (BRSDMKP), yang saat itu masih di kenal dengan Pusat Riset Wilayah Laut dan Sumber Daya Non Hayati, Badan Riset Kelautan dan Perikanan, ada sebanyak 463 titik kapal karam yang telah ditemukan di perairan Indonesia dan 42 dari titik tersebut sudah teridentifikasi (Mulyadi, 2014). Sementara UNESCO memperkirakan kapal karam tersebut di perairan Indonesia sekitar 500 titik yang tersimpan di bawah air seperti terlihat pada Gambar 1.

Kejadian kapal karam yang sudah berlangsung lama terjadi di Perairan Indonesia yang diperkirakan telah berlangsung sejak abad 1 Masehi), menyebabkan kondisi kapal karam dan barang muatannya saat ditemukan telah ditutupi oleh sedimen dan berada
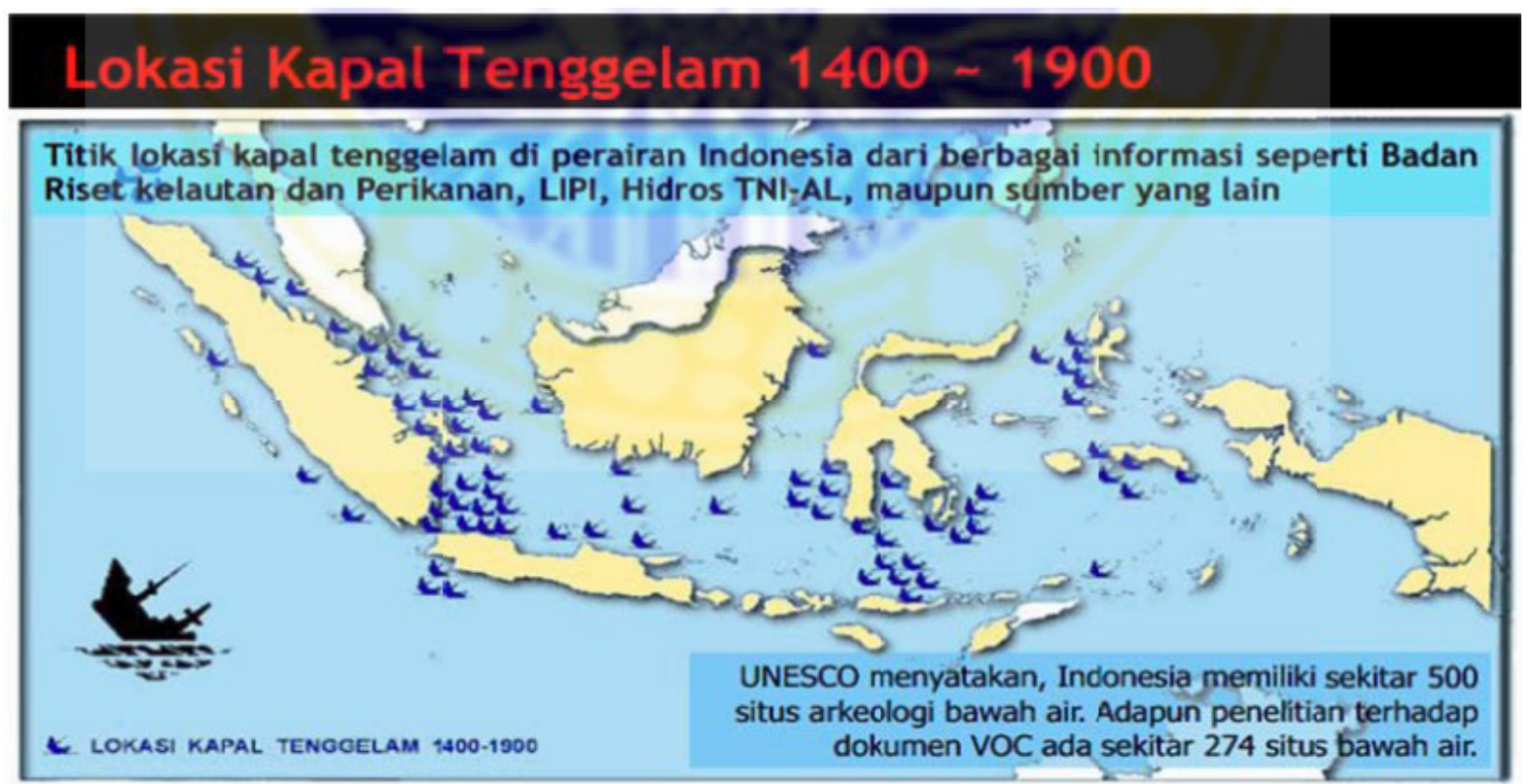

Gambar 1. Lokasi kapal tenggelam di wilayah Indonesia yang terlaporkan, diperkirakan tenggelam pada tahun sejak 1400-1900 M (Ibid, 2014).

Figure 1. Shipwrecks location around Indonesia which were reported. Those ships shanked about since 1400-1900 (Ibid, 2014)

JURNAL KELAUTAN NASIONAL, Vol. 12, No 3, Desember 2017, Hal. 141-150 
dibawah kawasan terumbu karang. Banyak kapal tenggelam ditemukan pada posisi di perairan dangkal pada kedalaman $1 \mathrm{~m}$ hingga $30 \mathrm{~m}$. Pada kedalaman tersebut terumbu karang dapat tumbuh dengan baik terutama di perairan Indonesia bagian timur yang tingkat kecerahannya masih bagus. Sementara kapal yang karamnya berada pada kedalaman diatas $30 \mathrm{~m}$, biasanya tutupan dan populasi karang sudah berkurang. Dengan demikian, perlu dilakukan pengamatan asosiasi karang dengan lokasi tempat kapal karam tersebut.

Aktifitas pengambilan dan pengangkatan artefak diduga dapat menimbulkan terjadinya sedimentasi yang dapat membahayakan kelangsungan hidup komuditas hewan laut yang ada di sekitar lokasi termasuk, seperti proses rekruitmen larva baru dan kerusakan terumbu karang secara langsung. Aktivitas pengangkatan secara illegal saat ini sering mengangkat dan memindahkan koloni karang yang tumbuh diatas lokasi artefak, sehingga koloni karang tidak pada posisinya, terguling dan terpaksa pindah ke posisi lain, bahkan bagian atas koloni berubah menjadi bagian bawah yang terdapat sedimen atau pasir sehingga karang dapat mengalami kematian.

Penelitian ini betujuan untuk melihat tutupan karang hidup di sekitar lokasi, tingkat rekruitmen dan melakukan observasi tingkat keanekaragaman jenis karang dan biota lainnya yang ada di lokasi kapal karam. Data ini akan dianalisa untuk mendapatkan tingkat dampak keberadaan artefak kapal karam dengan ekosistem terumbu karang bila dilakukan pengangkatan, baik secara illegal maupun secara resmi dengan melibatkan instansi pemerintah.

Pengamatan lokasi kapal karam dengan ekosistem terumbu karang ini penting dilakukan untuk mengetahui keberadaan terumbu karang di artefak kapal karam dan mengetahui dampak aktivitas pengangkatatan artefak yang ada pada kapal tersebut dan dapat membantu kebijakan dimasa akan datang terkait pengelolaan situs tersebut, sekiranya perlu pengembangan kearah pariwisata.

\section{BAHAN DAN METODE}

\section{Lokasi penelitian}

Penelitian dilakukan pada Situs Karang Semapi, Perairan Klarik Dalam, Pulau Natuna pada bulan April 2016, Mei 2017, dan September 2017. Berdasarkan jenis dan ciri sebaran artefak kapal karam yang ditemukan pada lokasi ini, diperkirakan dari masa Dinasti Song (960-1270) - Yuan (1271-1368) berdasarkan hasil identifikasi situs kapal karam yang dilakukan oleh Dillenia et al. (1996). Lokasi artefak dan pengumpulan data berada pada kedalaman 9 - $12 \mathrm{~m}$.

Artefak ditemukan telah ditutupi oleh pasir dan sebagian berada dibawah terumbu karang, sehingga untuk mendapatkannya harus menggali dan



Gambar 2. Lokasi penelitian pada Situs Kelarik Dalam, Perairan Karang Semapi, Natuna (Sumber: Hasil Pengolahan Data Pusris Kelautan, 2017)

Figure 2. Research location at Kelarik Dalam Site, Semapi reef waters area of Natuna (Resource: Marine Research Center, 2017) 
memindahkan karang. Dampak pengambilan artefak ini mengakibatkan banyak ditemukan koloni karang terbalik dan adanya tumpukkan karang pada beberapa sisi lokasi. Aktifitas pengambilan artefak ini dapat menyebabkan kematian karang dimana pada saat ini tergolong kegiatan yang ilegal, namun sering ditemukan indikasi aktifitas tersebut. Pada lokasi ditemukan artefak, karang dapat tumbuh dan hidup, tidak terdampak oleh tingginya kekeruhan yang diindikasikan dari nilai padatan tersuspensi atau Total Suspended Solid (TSS), hasil penelitian di daerah Natuna nilai TSS berkisar 3-26 mg/L, sebagaimana disyaratkan baku mutu KLH No. 51 Tahun 2004 untuk karang 20 mg/L (Pranowo et al., 2012).

\section{Pengamatan Tutupan Karang Hidup}

Pengambilan data dilakukan dengan mengunakan metode foto transek bawah air dengan menggunakan quadran berukuran $58 \mathrm{~cm} \times 44 \mathrm{~cm}$ yang dilakukan pada setiap $1 \mathrm{~m}$ (Giyanto, 2012) disepanjang transek garis $30 \mathrm{~m}$ kearah utara dan selatan, serta kearah timur dan barat, dimana posisi artefak berada pada titik tengah transek. Jarak dari posisi artefak dibagi menjadi tiga yaitu jarak terdekat dengan artefak antara 0-10 m dilakukan pada 4 transek (T\#), yaitu T3, T4 pada garis transek Utara-Selatan dan T9, T10 pada posisi Timur - Barat. Jarak sedang antara 10-20 m diwakili oleh transek T2, T5 untuk posisi Utara-Selatan, dan T8, T11 untuk posisi Timur-Barat. Sementara terjauh dari artefak antara 20-30 m diwakili oleh T1, T6 pada posisi Utara-Selatan dan T7, T12 pada posisi TimurBarat. Penggunaan metode foto quadrat mengikuti Giyanto et al. (2012) dengan menggunakan kamera bawah air Cannon G16.

\section{Analisa Data dan Uji Statistik}

Data dianalisa dengan menggunakan program komputer Coral Point Countwith Excel extension (CPCe) yang dikeluarkan oleh NCRI (National Coral Reef Institute) dan Nova South Eastern University (Kohler \& Gill, 2006) dengan menetapkan jumlah sampel data sebanyak 30 data setiap frame foto quadran. Data substrat diidentifikasi berdasarkan bentuk pertumbuhan dan kriteria substrat lain berdasarkan English et al. (1997). Tutupan karang hidup diklasifikasikan kepada tutupan sangat bagus $(>75 \%)$, bagus $(50-75 \%)$, jelek $(25-50 \%)$ dan sangat jelek $(<25 \%)$ berdasarkan klasifikasi Gomez \& Yap (1984), dan Giyanto et al., 2017. Pengamatan juga dilakukan untuk mendapatkan tingkat recruitment larva karang baru sepanjang $10 \mathrm{~m}$ dengan lebar $1 \mathrm{~m}$ masing-masing kiri dan kanan transek di bagian utara garis transek pada posisi meteran ke $9 \mathrm{~m}$.

Kemudian data dilakukan pengujian secara statistik dengan menggunakan RAL (Rancangan Acak Lengkap) pola faktorial 3x11 dengan 4 ulangan (Steel \& Torrie, 1993). Faktor pertama sebagai pelakuan yaitu jarak (0-10 m, 10-20 m, 20-30 m) dan jenis substrat yang memiliki 11 jenis yaitu HC (hard coral), DC (recently dead coral), DCA (dead coral with algae), SC (soft coral), SP (sponge), FS (fleshy seaweed), OT (otherbiota), R (rubble), SI (silt) dan RK (rock).

Data tutupan substrat yang diperoleh diolah dengan menggunakan analisis ragam (Anova), dengan tingkat kepercayaan pada 95\%. Model rancangan yang digunakan adalah sebagai berikut:

$Y i j k=\hat{U}+A i+B j+(A B) i j+\sum i j k$

Dimana:

Yijk nilai pengmatan untuk faktor jarak level ke-i, faktor jenis substrat level ke-j

$\hat{U} \quad$ : nilai tengah umum

Ai : pengaruh jarak dari lokasi artefak pada level ke-i

$\mathrm{Bj} \quad$ : pengaruh faktor jenis substrat pada level ke-j

(AB)ijk : interaksi faktor jarak pada lebel ke-I, jenis substrat ke-j

$\sum$ ijk : galat percobaan untuk jarak level ke-I, jenis substrat ke $\mathrm{j}$ dan ulangan ke-k

\section{Pengamatan Kualitas Perairan}

Pengukuran kualitas air ini menggunakan Water Quality Checker (WQC -24) dengan sensor module WMS-24-1-21 dan nomer serial 584602. Pengukuran dilakukan di permukaan perairan (kedalaman 0 - 1,5 m). Parameter kualitas perairan yang diukur pada survei ini antara lain kedalaman, derajat keasaman $(\mathrm{pH})$, oksigen terlarut (DO), suhu permukaan laut (temperatur), salinitas air laut, TDS dan turbiditas di sekitar lokasi dengan radius $1 \mathrm{~km}$ dari lokasi artefak. Parameter ini merupakan parameter utama yang menggambarkan kondisi perairan.

\section{HASIL DAN PEMBAHASAN}

Tutupan karang hidup (HC) terlihat pada transek yang dekat (jarak $10 \mathrm{~m}$ ) dengan lokasi artefak pada kuadran $10 \mathrm{~m}$ (T3 dan T4) disepanjang garis transek Utara Selatan lebih rendah dibandingkan dengan jarak ke 
artefak lain, demikian juga pada transek T9 dan T10 pada transek arah Timur - Barat, seperti terlihat pada Gambar 3.

Tutupan karang hidup secara keseluruhan berdasarkan rata-rata diperoleh tutupan tertinggi ditemukan pada posisi jarak $10-20 \mathrm{~m}(20,33 \%)$, diikuti jarak terjauh $(20-30 \mathrm{~m})$ sebesar $18,5 \%$ dan terendah pada jarak terdekat $(0-10 \mathrm{~m})$ dengan tutupan sebesar $6.88 \%$ Tutupan karang hidup tertinggi ditemukan pada salah satu transek yaitu transek $6(36 \%)$ pada posisi $20-30 \mathrm{~m}$ dari pusat artefak (Gambar 3).

Rendahnya tutupan karang hidup pada lokasi terdekat (0-10 m) dengan lokasi artefak diperkuat oleh data ratarata patahan karang (rubble) yang tinggi $(26,4 \%)$ dan bongkahan karang mati berukuran besar (rock) sebesar $50,4 \%$. Tutupan rock terbesar berikutnya ditemukan pada jarak sedang (10-20 m) sebesar 35,6 dan jarak terjauh sebesar $31,9 \%$.

Secara keseluruhan tutupan karang hidup masih berada pada klasifikasi kondisi jelek dimana tutupan karang hidupnya berada pada kisaran antara 26 - 50\% (Gomes \& Yap, 1984; Giyanto et al., 2017). Bahkan tutupan tertinggi pada transek 6 sebesar $36 \%$ masih berada pada klasifikasi kondisi karang jelek. Tutupan karang ini masih lebih rendah dibandingkan pada lokasi yang dalam proses pemulihan yang terjadi di Perairan Kota Padang, dimana lokasi terbaik ditemukan pada transek permanen sebesar $65,58 \%$ (Johan et al., 2014), jauh lebih rendah pada lokasi yang terinfeksi penyakit Black Band Disease di Kepulauan Seribu dimana pada lokasi ini memiliki tutupan terendah ke tutupan tertinggi berkisar antara 57,17\% - 76,88\% (Johan et al., 2013), juga lebih rendah dibandingkan dengan 9 pulau hasil survei Belitung Timur dengan kisaran antara 51,31 78,18\% (Johan et al., 2015). Berdasarkan perbandingan tutupan ini dapat dijelaskan bahwa kondisi karang di lokasi artefak sedang mengalami tekanan akibat aktifitas pengambilan artefak dan kondisi tekanan lingkungan lainnya di sekitar lokasi penelitian.

Hasil analisa statistik dengan menggunakan SPSS melalui analisa varian dengan membandingkan rataan presentase substrat, terdapat perbedaan sangat nyata terhadap rataan jenis substrat, interaksi antara jenis substrat dengan perbedaan jarak juga berbeda sangat nyata $(\mathrm{P}=0,00)$ pada tingkat kepercayaan $95 \%$.

Adanya presentase tutupan patahan karang (rubble) dan rock dapat menjelaskan bahwa aktifitas pengambilan artefak dapat berdampak terhadap menurunnya tutupan karang hidup terrutama pada lokasi terdekat lebih rendah dibandingkan dengan lokasi sedang dan terjauh dari lokasi artefak. Kondisi tersebut disebabkan aktifitas pengangkatan artefak dapat merusak habitat karena secara langsung memindahkan koloni karang dari posisi alaminya. Proses pemindahan tidak berdasarkan prinsip kehati-hatian terhadap biota laut, sehingga posisi koloni karang terbalik dan membuat karang stress dan bahkan bisa menyebabkan kematian. Disamping itu, apabila pengambilan artefak dilakukan berulang kali membuat lokasi sering terpapar oleh tingginya tingkat turbiditas karena aktifitas pengambilan dapat melakukan penggalian yang membuat sedimen terangkat yang menyebabkan perairan menjadi keruh. Kondisi ini tergantung pada arus di lokasi, sekiranya arusnya tinggi maka kekeruhan dapat teratasi dengan terbawa arus ke lokasi lain secara merata sehingga mengurangi dampak di sekitar lokasi artefak. Hal ini terbukti disaat melakukan pengamatan, gerak fin dapat mengangkat pasir halus (silt) ke badan perairan sehingga perairan sekitar lokasi menjadi keruh. Lamanya untuk kembali jernih lagi tergantung oleh adanya arus. Arus akan membantu padatan tersuspensi ke lokasi lain, sehingga tingkat kecerahan di lokasi pengambilan data kembali baik.

Namun apabila kondisi arus tidak ada, maka dampak stress terhadap karang semakin besar. Makanya tingkat tutupan karang hidup lebih rendah, sementara rubble dan rock sangat tinggi pada lokasi terdekat dari lokasi artefak kapal karam. Berdasarkan hasil pengujian kondisi lingkungan akibat sedimen dan turbiditas yang dilakukan oleh Pollock et al. (2014), menyatakan bahwa dua faktor ini sebagai penyebab utama terjadinya prevalensi penyakit karang dan faktor penganggu kesehatan karang yang dapat menyebabkan turunnya tutupan karang nantinya. Kemudian Carpenter et al. (2008) menyatakan bahwa sepertiga hilangnya karang di kawasan dalam skala global disebabkan salah satunya adalah oleh dampak lokal seperti dampaknya antropogenik.

Dampak terhadap karang terlihat sudah lama berlangsung karena tidak ada inikasi kematian karang yang baru saja terjadi. Pada Gambar 3 terlihat parameter substrat jenis DC (Recent Dead Coral) tidak ditemukan di lokasi. Kemungkinan aktifitas pengambilan artefak paling terakhir sudah berlangsung 3 minggu sebelumnya atau lebih, berdasarkan informasi dari peneliti yang bulan sebelumnya datang ke lokasi yang sama menyatakan bahwa banyak perubahan areal artefak dimana gundukan bekas kalian lebih tinggi dibagian sisi dari lokasi artefak ditemukan. 


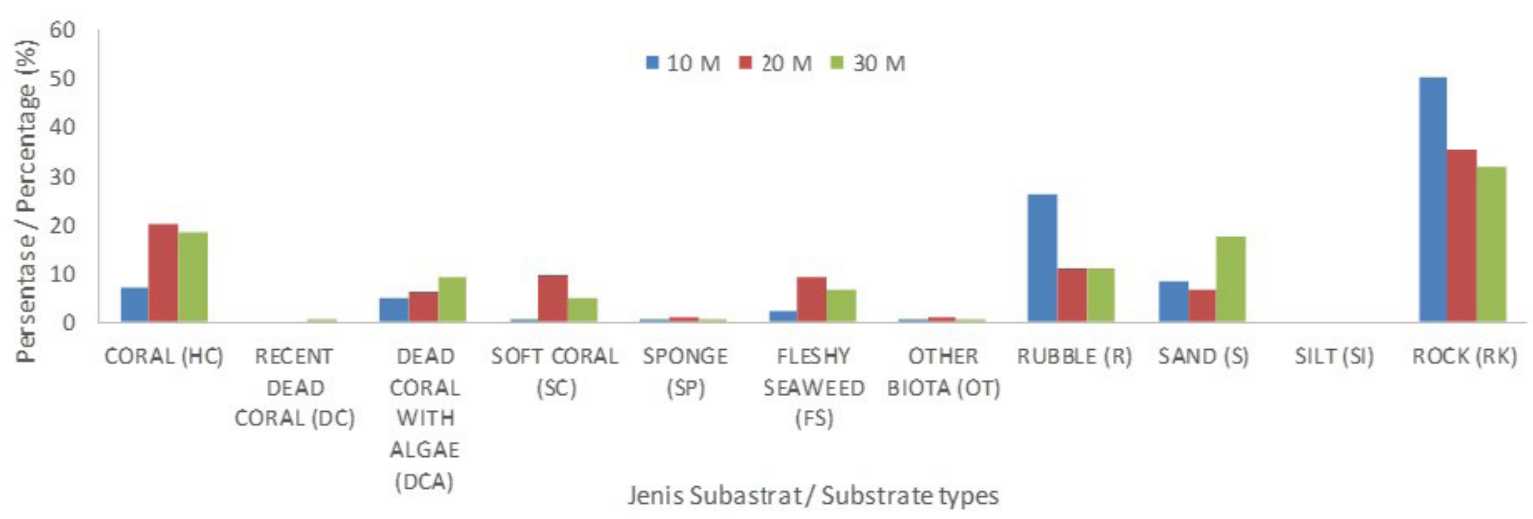

Gambar 3. Tutupan karang hidup (\%) pada transek disepanjang Utara-Selatan (T1 - T6) dan Timur - Barat (T7 - T12) sesuai jarak terdekat $(0-10 \mathrm{~m})$, sedang $(10-20 \mathrm{~m})$ dan terjauh $(20-30 \mathrm{~m})$ dari keberadaan artefak kapal tenggelam. Tutupan karang hidup (Coral-HC), karang baru mati (Recent Dead Coral-DC), karang telah ditutupi algae (Dead Coral with Algae-DCA), karang lunak (Soft Coral-SC), Spons (Sponge-SP), rumput laut (Fleshy Seaweed-FS), biota lain (Others-

$O T)$, patahan karang $($ Rubble-R), pasir (Sand-S), pasir halus (Silt-Si), bongkahan karang mati ukuran besar (Rock-RK).

Figure 3. Live coral cover (\%) on transect from North-South (T1-T6) and East o West (T7 - T12) based on nearest zone (0 - $10 \mathrm{~m})$, middle zone $(10-20 \mathrm{~m})$ and the farthest zone $(20-30 \mathrm{~m})$ from the artifact of ship wreck. Live coral cover (CoralHC), Recent Dead Coral-DC, Dead Coral with Algae-DCA, Soft Coral-SC, Sponge-SP, Fleshy Seaweed-FS, Others-OT, Rubble-R, Sand-S, Silt-Si, Rock-RK.

Penelitian berhasil mendata sebanyak 360 koloni pada T1 - T6 dan 510 koloni pada T7 - T12. Demikian juga jumlah jenis karang keras sebanyak 25 genera, lebih rendah pada T1 - T6 dibandingkan dengan jumlah jenis pada T7 - T12 yaitu 33 genera.Sebagian telah teridentifikasi dalam tingkatan spesies. Jumlah koloni karang keras tertinggi ditemukan pada jenis Porites lutea $(52 \& 74 \mathrm{kol})$, Favites $s p(43 \& 31 \mathrm{kol})$, Favia $s p(24 \& 58 \mathrm{kol})$ untuk masing-masing bagian sisi T1 - T6 dan transek T7 - T12. Sedangkan biota lain yang berhasil teridentifikasi sebanyak 9 genera yang didominansi jenis karang lunak yaitu Sarcophyton $s p$ (25 dan $34 \mathrm{kol})$ dan Lobophytum sp (59 dan $93 \mathrm{kol}$ ) untuk masing-masing bagian sisi T1 - T6 dan transek $\mathrm{T} 7$ - T12. Jumlah koloni dan jenis karang yang temukan ini dapat dilihat secara rinci di Tabel 1.

Meskipun tutupan karang hidupnya rendah, namun pada lokasi ini memiliki jumlah jenis karang yang tinggi dibandingkan dengan dengan beberapa lokasi diantaranya lokasi di Kepulauan Seribu masih dibawah 30 genera dari 13 lokasi yang diamati (Johan, 2004), lokasi perairan Kota Padang dengan 6 lokasi transek permanen dimana hanya ditemukan berkisar 9 - 15 genera (Johan et al., 2016), tapi lebih tinggi di pulau Ketapang, Belitung Timur sebanyak 34 genera dari 2 titik pengamatan (Johan et al., 2016).

Tingkat recruitment karang pada bagian lokasi artefak berkisar antara $0.06-0.56 \mathrm{kol} / \mathrm{m}^{2}$ (Tabel 3). Tingkat rekruitmen ini termasuk rendah berdasarkan klasifikasi yang dibuat oleh Obura \& Grimsdith (2009), dimana masih berada dibawa 1 koloni per meter persegi. Jenis karang yang tinggi recruitment-nya adalah Porites, Favia sementara terendah dengan kelimpahan 0.11 $\mathrm{kol} / \mathrm{m}^{2}$ terjadi pada genera karang Coscinarae, Fungia 2, Hydnophora exesa, Lobophytum, Montipora dan Scolymia. Ada 12 jenis karang keras scleractinian dan 2 jenis karang lunak yang berhasil ditemukan recrutiment karang disekitar lokasi artefak kapal tenggelam.

Kelimpahan rekruitmen karang di pulau Pari ditemukan sebesar $3,22 \mathrm{kol} / \mathrm{m}^{2}$ dinyatakan tergolong rendah (Wibowo et al., 2016), sementara di lokasi penelitian ditemukan tertinggi sebesar $0,56 \mathrm{kol} / \mathrm{m}^{2}$ dimana masih lebih rendah dibandingkan dengan di pulau Pari. Total jumlah genera karang rekruitmen di pulau Pari ditemukan sebanyak 25 genera dari 5 stasiun pengamatan, dengan kisaran terendah ke tertinggi dari masing-masing stasiun adalah antara 3 - 15 genera. Berarti jumlah genera di perairan Semapi hanya lebih rendah 3 genera dibandingkan dengan jumlah genera tertinggi disalah satu lokasi di pulau Pari, Kepulauan Seribu, Jakarta. Data rekruitmen ini menunjukkan bahwa lokasi di sekitar artefak berjarak sedang dan terjauh masih memungkinkan untuk anakan karang menempel, tumbuh dan hidup dengan kondisi normal, hanya saja pada lokasi terdekat terganggu dengan adanya kekeruhan yang sering terjadi akibat aktifitas pengangkatan artefak. 
Tabel 1. Jumlah jenis karang yang ditemukan pada area $120 \mathrm{~m}^{2}$ pada transek Utara-Selatan (T1-T6) dan BaratTimur (T7-T12)

Table 1. Coral species number which found on $120 \mathrm{~m}^{2}$ area of North-South Transect (T1-T6) and West-East Transect (T7-T12)

\begin{tabular}{|c|c|c|c|}
\hline No & $\begin{array}{l}\text { Jenis Karang } \\
\text { Coral species }\end{array}$ & $\begin{array}{l}\text { Utara-Selatan } \\
\text { North - South } \\
\text { (T1-T6) }\end{array}$ & $\begin{array}{l}\text { Barat-Timur } \\
\text { West - East } \\
\text { (T7-T12) }\end{array}$ \\
\hline
\end{tabular}

\begin{tabular}{|c|c|c|c|}
\hline & $\begin{array}{l}\text { Karang } \\
\text { Scleractinian } \\
\end{array}$ & & \\
\hline 1 & Acropora sp & 7 & 21 \\
\hline 2 & Acropora humilis & 3 & 1 \\
\hline 3 & Achantastrea sp & 2 & 2 \\
\hline 4 & Astreopora sp & 15 & 26 \\
\hline 5 & Cyphastrea sp & 4 & 8 \\
\hline 6 & Ctenactis $s p$ & 0 & 2 \\
\hline 7 & Coscinarae sp & 0 & 2 \\
\hline 8 & $\begin{array}{l}\text { Dendronephthya } \\
\text { sp }\end{array}$ & 10 & 5 \\
\hline 9 & Diploastrea sp & 21 & 16 \\
\hline 10 & Echinophora sp & 7 & 0 \\
\hline 11 & $\begin{array}{l}\text { Euphyllia } \\
\text { yaeyamensis }\end{array}$ & 0 & 0 \\
\hline 12 & Echinophora sp & 0 & 8 \\
\hline 13 & Favia sp & 24 & 58 \\
\hline 14 & Favites $s p$ & 43 & 31 \\
\hline 15 & Fungia sp & 4 & 0 \\
\hline 17 & Ctenactis sp & 1 & 0 \\
\hline 18 & Galaxea sp & 1 & 8 \\
\hline 19 & Galaxea archelia & & 1 \\
\hline 20 & Goniastrea sp & 1 & 2 \\
\hline 21 & Heliopora sp & 1 & 0 \\
\hline 22 & $\begin{array}{l}\text { Herpolitha } \\
\text { weberi }\end{array}$ & 0 & 2 \\
\hline 23 & Herpolitha sp & 0 & 2 \\
\hline 24 & Hydnophora sp & 5 & 0 \\
\hline 25 & $\begin{array}{l}\text { Hydnophora } \\
\text { microconus }\end{array}$ & 9 & 2 \\
\hline 26 & $\begin{array}{l}\text { Hydnophora } \\
\text { rigida }\end{array}$ & 0 & 1 \\
\hline 27 & Leptoseris sp & 0 & 1 \\
\hline 28 & Lobophyllia sp & 6 & 9 \\
\hline 29 & Merulina sp & 5 & 5 \\
\hline 30 & Montipora sp & 0 & 1 \\
\hline 31 & Oxypora sp & 1 & 1 \\
\hline 32 & $\begin{array}{l}\text { Pachyseris } \\
\text { rugosa }\end{array}$ & 5 & 5 \\
\hline 33 & $\begin{array}{l}\text { Pachyseris } \\
\text { spesiosa }\end{array}$ & 3 & 6 \\
\hline 34 & Pavona sp & 1 & 0 \\
\hline 35 & Pectinia sp & 0 & 2 \\
\hline 36 & Pectinia lactuca & 0 & 1 \\
\hline 37 & Platygyra sp & 10 & 26 \\
\hline 38 & Physogyra sp & 0 & 1 \\
\hline
\end{tabular}

\section{Lanjutan Tabel 1}

\begin{tabular}{|c|c|c|c|}
\hline 39 & Porites rus & 2 & 1 \\
\hline 40 & $\begin{array}{l}\text { Porites } \\
\text { cylindrica }\end{array}$ & 9 & 8 \\
\hline 41 & Porites lutea & 52 & 74 \\
\hline 42 & $\begin{array}{l}\text { Pocillopora } \\
\text { verrucosa }\end{array}$ & 4 & 3 \\
\hline 43 & $\begin{array}{l}\text { Pocillopora } \\
\text { damicornis }\end{array}$ & 0 & 1 \\
\hline 44 & Podabacia sp & 0 & 1 \\
\hline 45 & Psammocora sp & 0 & 1 \\
\hline 46 & Stylophora sp & 2 & 3 \\
\hline 47 & Symphyllia sp & 10 & 5 \\
\hline 48 & Scolymia sp & 0 & 2 \\
\hline \multirow[t]{2}{*}{49} & $\begin{array}{l}\text { Turbinaria } \\
\text { retiniformis }\end{array}$ & 0 & 1 \\
\hline & Biota lain & & \\
\hline 50 & Ascidian & 0 & 11 \\
\hline 51 & Gorgonian & 0 & 1 \\
\hline 52 & Linkia & 0 & 1 \\
\hline 53 & Sarcophyton sp & 25 & 34 \\
\hline 54 & Lobophytum sp & 59 & 93 \\
\hline 55 & Sponge & 0 & 1 \\
\hline 56 & Teripang & 0 & 2 \\
\hline 57 & Xenia & 1 & 0 \\
\hline 58 & Zooantids & 0 & 8 \\
\hline \multicolumn{2}{|c|}{ Jumlah koloni } & 360 & 510 \\
\hline \multicolumn{2}{|c|}{ Jumlah jenis } & 25 & 49 \\
\hline
\end{tabular}

\section{Kondisi Kualitas Air}

\section{Oksigen Terlarut (DO)}

Tingkat kandungan oksigen di perairan Karang Semapi cenderung seragam secara keseluruhan dan sangat baik untuk pertumbuhan biota laut. Nilai Sebarannya berkisar lebih dari $9 \mathrm{mg} / \mathrm{L}$ sedangkan menurut Kepmen $\mathrm{LH}$, batas minimum kandungan oksigen dalam air laut adalah $5 \mathrm{mg} / \mathrm{L}$. Kandungan oksigen tertinggi berada di atas perairan Karang Semapi yang memang berada di atas karang dan berada pada kedalaman yang dangkal. Didaerah terumbu karang, fitoplankton banyak melakukan fotosintesis dan menghasilkan oksigen, hal inilah yang menjadi pemicu tingginya kadar oksigen di Karang Semapi pada 2 titik lokasi pengukuran tersebut. Kandungan oksigen tertinggi mencapai 14,77 $\mathrm{mg} / \mathrm{L}$ di lokasi ini. Tingginya kadar oksigen berdampak baik pada kedidupan berbagai biota termasuk karang, pada perairan Jikumerasa, Pulau Buru diperoleh kadar oksigennya antara 5,57 - 5,96 mg/L dan sudah tergolong kondisi normal (Patty et al., 2015). Semakin tinggi kadar oksigen maka biota yang hidup dilokasi tersebut semakin baik mendapatkan oksigen yang dibutuhkan dalam pernapasannya. 
Tabel 2. Rekruitmen karang pada pengamatan luasan $18 \mathrm{~m}^{2}$

Table 2. Coral recruitment on observation area in $18 \mathrm{~m}^{2}$

\begin{tabular}{lll}
\hline Jenis/Species & $\begin{array}{l}\text { Jumlah koloni// } \\
\text { Colony No. }\end{array}$ & $\begin{array}{l}\text { Kelimpahan }\left(\mathbf{c o l} / \mathbf{m}^{2}\right) \\
\text { Abundance }\end{array}$ \\
\hline Achantastrea $s p$ & 7 & 0,39 \\
Acropora $s p$ & 3 & 0,17 \\
Astreopora $s p$ & 5 & 0,28 \\
Coscinarae $s p$ & 1 & 0,06 \\
Cyphastrea $s p$ & 3 & 0,17 \\
Favia sp & 10 & 0,56 \\
Favites sp & 8 & 0,44 \\
Fungia spp & 2 & 0,11 \\
Hydnophora & 1 & 0,06 \\
exesa & & \\
Montipora $s p$ & 1 & 0,06 \\
Porites sp & 9 & 0,50 \\
Scolymia $s p$ & 1 & 0,06 \\
Lobophytum sp & 1 & 0,06 \\
Sarcophyton sp & 4 & 0,22 \\
\hline
\end{tabular}

Maksimum: 0,56 Minimum: 0,06

Suhu (Temperatur)

Nilai sebaran suhu cenderung homogen di sekitar lokasi penelitian. Nilai suhu permukaan laut(SPL) ini biasanya terlihat berbeda setelah perbedaan musim. Suhu juga sangat terpengaruh dengan variasi harian secara jam dan kedalaman. Pada kedalaman yang dangkal, suhu permukaan laut akan lebih hangat dibanding dengan SPL pada perairan dalam. Hal ini terlihat di daerah perairan Semapi, karena kontur kedalaman yang dangkal, membuat kondisi SPL di lokasi tersebut sedikit lebih hangat dibandingkan dengan sekitarnya. SPL terendah terlihat berada di bagian utara, hal ini merupakan akibat masuknya massa air laut dalam dari Laut China Selatan ke Perairan Natuna yang membawa massa air yang cenderung lebih dingin. Nilai SPL di sekitar lokasi survei ini berkisar antara $30-31^{\circ}$ Celcius. Nilai ini masih masih masuk dalam rentang suhu yang dibutuhkan, namun pada batas atas lebih tinggi 1 ${ }^{\circ}$ Celcius, apabila dibandingkan dengan pendapat Kordi (2010) yang menyatakan suhu yang dibutuhkan untuk pembentukan terumbu karang adalah $25-30^{\circ} \mathrm{C}$.

\section{Salinitas}

Sebaran salinitas di lokasi survei berkisar antara 30 PSU. Perbedaan nilai Salinitas biasanya lebih banyak dipengaruhi oleh pergerakan massa air dan kondisi musim di Indonesia. Salinitas di sekitar perairan cenderung homogen tanpa ada perbedaan yang mencolok. Nilai salainitas ini berada pada kondisi yang cocok untuk pertumbuhan karang dengan baik. Hal ini menandakan bahwa kondisi ini memang sesuai dengan musim peralihan dari musim Timur menuju Musim Barat. Hasil data yang diperoleh ini sangat cocok untuk tumuh karang, Dahuri (2003) mengatakan untuk wiayah yang dekat dengan pesisir salinitas untuk pertumbuhan karang dapat berkisar 30 - 35 PSU. Hasil pengolahan data DO, SPL, dan Salinitas tertera pada Gambar 5.
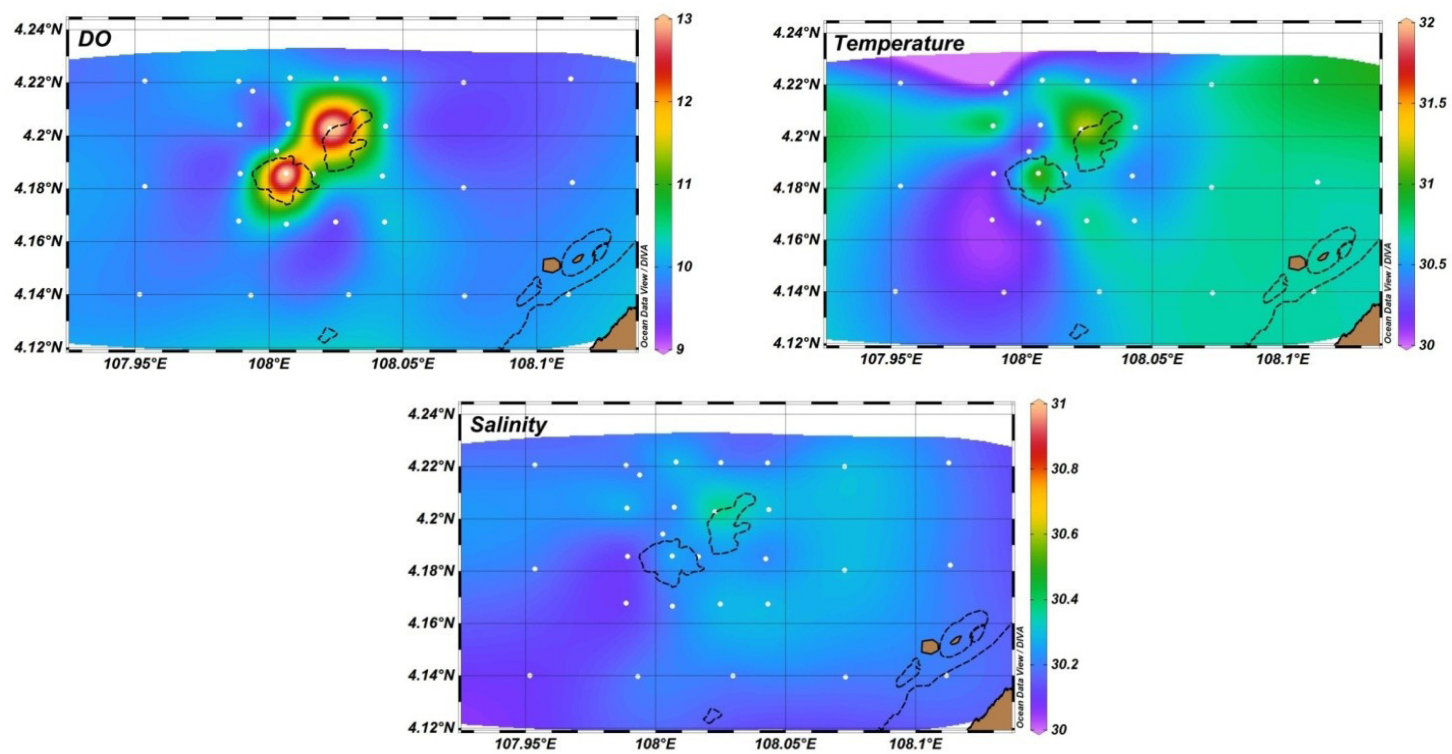

Gambar 4. Peta sebaran DO, temperatur, dan Salinitas kolom air laut Kelarik (hasil pengolahan data Pusris Kelautan, 2017).

Figure 4. Map distribution of DO, temperature and salinity on marine water in Kelarik (analysis result of Marine Research Center, 2017) 


\section{Total Dissolved Solid}

TDS (Total Dissolved Solid) atau total padatan terlarut adalah bahan-bahan terlarut (diameter $<10-6 \mathrm{~mm}$ ) dan koloid (diameter $10-6$ dan $10-3 \mathrm{~mm}$ ) berupa senyawa-senyawa kimia dan bahan-bahan lainnya (organik dan anorganik) yang dapat melewati filter berukuran 2 mikron.

Sebaran nilai TDS di area survei berkisar dinilai 49 $\mathrm{mg} / \mathrm{L}$ sehingga masih sangat baik kualitas perairannya dinilai dari parameter TDS.

\section{Kekeruhan}

Kekeruhan (Turbidity) adalah digunakan untuk menyatakan derajat kegelapan di dalam air yang disebabkan oleh bahan-bahan yang melayang. Batasan nilai kekeruhan menurut Permenkes No. 461 tahun 1990 untuk air bersih adalah 25. Nilai kekeruhan di area survei bernilai 0 di semua stasiun pengukuran sehingga termasuk perairan yang baik/jernih.

\section{KESIMPULAN DAN SARAN}

Lokasi artefak memiliki dampak terhadap penurunan tutupan karang hidup yang ditandai dengan rendahnya tutupan karang hidup pada lokasi terdekat $(6,9 \%)$ dan didukung oleh data tingginya patahan karang $(26,4 \%)$ dan rock (50,4\%) yang sebelumnya merupakan karang hidup. Kegiatan pengangkatan artefak diharapkan

dapat dilakukan dengan bijak apabila lokasi berasosiasi dengan karang yang kondisinya dalam keadaan baik dan sangat baik. Parameter lingkungan sebagai indikator terjadinya gangguan yang akan berdampak terhadap kehidupan karang dan biota lainnya.

\section{UCAPAN TERIMA KASIH}

Kegiatan penelitian ini didukung oleh kerjasama antara Badan Riset dan Sumber Daya Manusia dan Direktorat Jenderal Pengelolaan Ruang Laut dan Dukungan dana. Pelaksanaannya di lapangan dibantu oleh tenaga dari semua tim lintas instansi. Semua kontribusi baik anggaran dan tenaga tim survei kami ucapkan terima kasih.

Artikel ini telah dipresentasikan di acara Seminar Nasional Kelautan Pada Gelar Riset dan Inovasi Teknologi Kelautan dan Perikanan, 24 - 27 Oktober 2017 di Jakarta.

\section{DAFTAR PUSTAKA}

Carpenter, K. E., Abrar, M., Aeby, G., Aronson, R., Banks, S., Bruckner, A, et. al. (2008). One-third of ReefBuilding Coral Face Elevated Extinction Risk from Climate Change and Local Impacts. Science, 321:560-563.

Dahuri, R. (2003). Keanekaragaman Hayati Laut. PT. Gramedia Pustaka Utama. Jakarta.412p.

Dellinea, I., \& Troa, R. A. (1996). Identifikasi situs kapal karam bersejarah "Kapal Panjang” di Perairan pulau
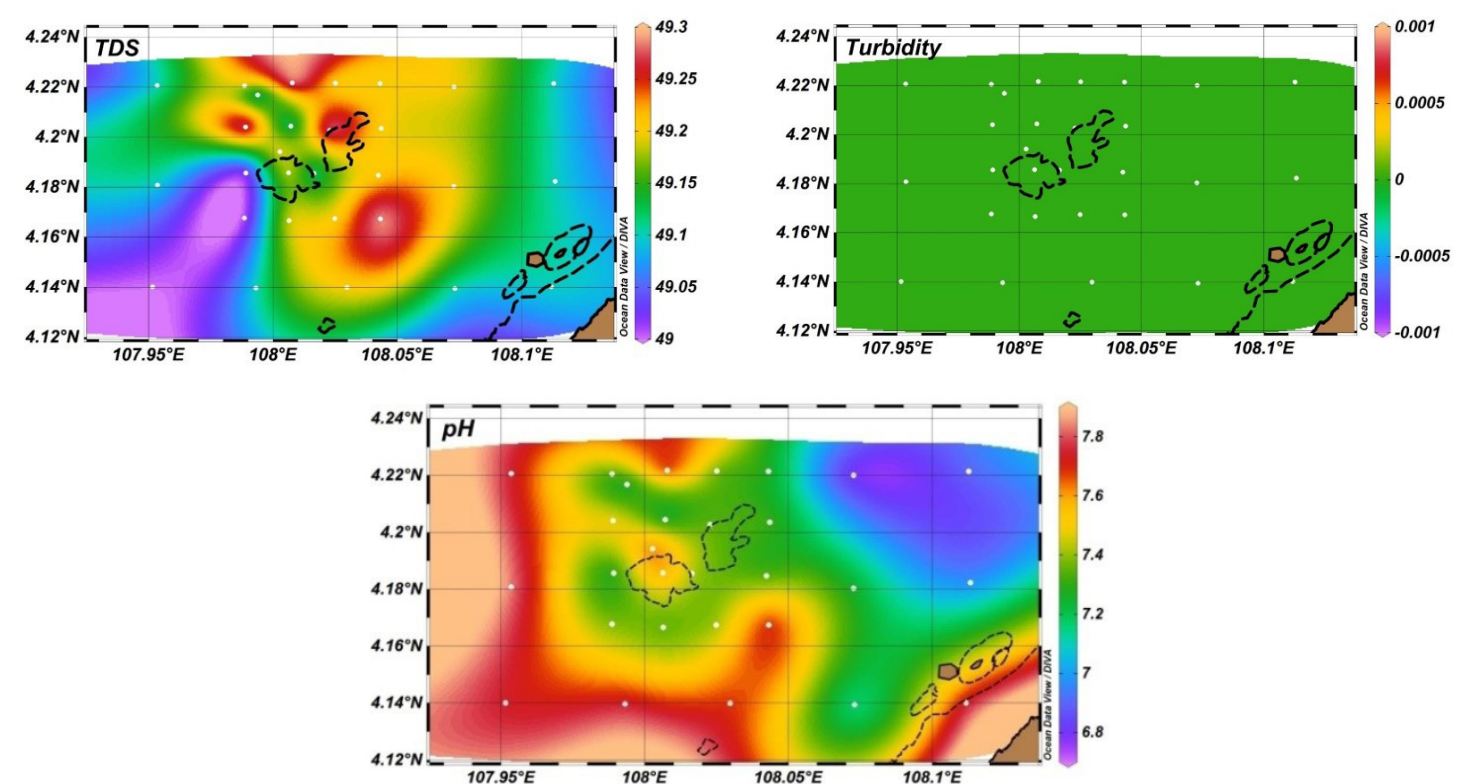

Gambar 5. Peta sebaran TDS, turbiditas dan pH air laut Kelarik (hasil pengolahan data Pusris Kelautan, 2017).

Figure 4. Map distribution of TDS, turbiditas and pH on Kelarik marine water

(analysis result of Marine Research Center, 2017.

Dampak Pengangkatan Artefak Bawah Laut Terhadap Kerusakan Terumbu Karang Berdasarkan Indikator Tutupan Substrat dan Parameter Lingkungan - Ofri Johan, Ira Dillenia, Rainer Arif Troa dan Eko Triarso 
Laut Natuna. Jurnal Kelautan Nasional, 11(1): 11-20.

English, S., Wilkinson, C., \& Baker, V. (1997). Survey Manual for Tropical Marine Resources. Ed ke-2. Townsville: AIMS. 390p.

Giyanto, Abrar, M., Hadi, T. A., Budiyanto, A., Hafizt, M., Salatalohy, A., \& Iswali, Y. M. (2017). Status terumbu karang Indonesia 2017. COREMAP-CTI. Pusat Penelitian Oseanografi-LIPI, Jakarta.

Giyanto. (2012). Penilaian Kondisi Terumbu Karang Dengan Metode Transek Foto Bawah Air. Oseanologi dan Limnologi di Indonesia 38 (3): 377-390.

Gomez, E. D. \& Yap, H. T. (1984). Monitoring reef condition. Dalam Kenchington R A. and B. Hudson E. T. (ed). Coral reef Management Hand Book. Unesco Regional Office for Science and Technology for South East Asia. Jakarta. 171 p.

Ibid. (2014). Kebijakan Pelestarian Cagar Bawah Air. Direktorat Pelestarian Cagar Budaya dan Permuseuman.

Johan, O. (2004). Kondisi ekosistem terumbu karang sebagai sumberdaya perikanan di Kepulauan Seribu, Jakarta. Warta-Penelitian Perikanan Indonesia, Edisi Akuakultur, 10(2):2-6.

Johan, O., Bengen, D. G., Zamani, N. P., \& Suharsono. (2013). Distribusi dan kelimpahan penyakit karang sabuk hitam secara spasial di Kepulauan Seribu, Jakarta. Jurnal Riset Akuakultur, 8(3):439-451.

Johan, O., Ginanjar, R., \& Priyadi, A. (2015). Coral health levels of wild ornamental coral in East Belitung waters, Indonesia. Nusantara Bioscience, 7(2):127132.

Johan, O., Prasetio, A. B., Ardi, I., Syam, A. R., \& Quin, N.J. (2016). The abundance of ornamental corals after mass die off in 1997 On the padang shelf reef system, west sumatera, indonesia. Jurnal Ilmu dan Teknologi Kelautan Tropis, Vol. 8, No. 1, Hlm. 29-38.

Johan, O., Priyadi, A., Hadie, W., \& Herminawati, S. C. (2016). Survai dan inventarisasi karang hias dan ikan hias laut di pulau Ketapang, Belitung Timur. Prosiding Forum Inovasi Teknologi Akuakultur. 399405.

Johan, O., \& Syam, A. R. (2014). Scleractinian coral health status of Padang Shelf Reef System, West Sumatra, Indonesia. Ilmu Kelautan, 19(4):181-188.

Kohler, K. E., \& Gill, S. (2006). Coral Point Count with Excel extensions (CPCe): A Visual Basic program for the determination of coral and substrate coverage using random point count methodology. Computers \& Geosciences 32(9):1259-1269. ix + 30 hlm.; 17,6 $\mathrm{cm} \times 25 \mathrm{~cm}$.

Kordi, K. M. G. H. (2010). Ekosistem terumbu karang. Rineka Cipta. Jakarta. $212 \mathrm{hlm}$.

Mulyadi, Y. (2014). Potensi cagar budaya bawah air. Bahan ajar Arkeologi Maritim Jurusan Arkeologi, Fakultas Sastra, Universitas Hasanuddin. 16 p.

Obura, D. O., \& Grimsdith, G. (2009). Resilience Assessment of coral reefs - Assessment protocol for coral reefs, focusing on coral bleaching and thermal stress.
IUCN working group on Climate Change and Coral Reefs. IUCN, Gland, Switzerland. 70 pp.

Patty, S. I., Arfah, H., \& Abudl, M. S. (2015). Zat hara (Fosfat, Nitrat), oksigen terlarut dan $\mathrm{pH}$ kaitannya dengan kesuburan di perairan Jikumerasa, Pulau Buru. Jurnal Pesisir dan Laut Tropis, 1(1):43-50.

Pranowo, W. S., Puspita, C. D., Adi, R. A., Kuswardani, A. R. T. D., \& Dewi, L. C. (2012). Atlas sumberdaya laut dan pesisir Natuna dan sekitarnya. B. Sulistiyo, Tukul R. Adi, Triyono (Eds.). Pusat Penelitian \& Pengembangan Sumberdaya Laut dan Pesisir, Badan Penelitian dan Pengembangan Kelautan \& Perikanan, Kementerian Kelautan dan Perikanan, Republik Indonesia. $148 \mathrm{p}$.

Pollock, F. J., Lamb, J. B., Field, S. N., Heron, S. F., \& Schaffelke, B. (2014). Sediment and Turbidity Associated with Offshore Dredging Increase Coral Disease Prevalence on Nearby Reefs. PLoS ONE 9(7):e102498. doi:10.1371/journal.pone.0102498.

Wibowo, K., Abrar, M., \& Siringoringo, R. M. (2016). Status tropic ikan karang dan hubungan ikan herbivora dengan rekruitmen karang di perairan pulau Pari, Teluk Jakarta. Oseanologi dan Limnologi di Indonesia. 1(2):73-89.

JURNAL KELAUTAN NASIONAL, Vol. 12, No 3, Desember 2017, Hal. 141-150 